\title{
PENINGKATAN KEMAMPUAN PENDIDIK PENDIDIKAN NONFORMAL DALAM IMPLEMENTASI PEMBELAJARAN
}

\author{
Nursam*
}

\begin{abstract}
The role of educator in non-formal education is essential to succeed the non-formal education programs. This article discusses some theoretical knowledge about learning and teaching to improve the educator's competence. The writer believes that the educators in non-formal education will be able to improve their performance by implementing the theories discussed in this article.
\end{abstract}

Keywords: competence, educator in non-formal education, instruction in non-formal of education.

\section{PENDAHULUAN}

Pendidikan Nasional terdiri atas tiga sub sistem yaitu subsistem pendidikan formal, dan subsistem pendidikan nonformal, dan subsistem pendidikan informal atau yang berlangsung dalam lingkungan keluarga, sebagaimana diatur dalam Undang-Undang Nomor 20 Tahun 2003. Sebagaimana unsur-unsur dalam sistem, kedua sistem pendidikan tersebut mempunyai komponen proses dan tujuan. Subsistem pendidikan formal memiliki komponen masukan sarana (instrumental input), masukan mentah (raw input), proses, dan keluaran (output) sebagai tujuan institusional pendidikan. Adapun subsistem pendidikan luar sekolah memiliki komponen yang terdiri atas masukan lingkungan (environmental input), masukan sarana (instrumental input), masukan mentah (raw input), dan masukan lain (other input), proses dan tujuan yang mencakup keluaran (output) sebagai tujuan antara dan pengaruh atau dampak (outcome) sebagai tujuan akhir intruksional pendidikan.

Dalam suatu pendekatan sistem, terdapat beberapa komponen yang harus ada dalam pembelajaran, di mana antara komponen satu dengan lainnya harus saling berkaitan. Komponen tersebut adalah tujuan, peserta didik, pendidik, materi pembelajaran, dan lingkungan belajar. Pembelajaran dilaksanakan dalam upaya terjadinya proses belajar dalam diri peserta didik. Terjadinya proses pembelajaran pada diri peserta didik harus diupayakan dengan melakukan desain pembelajaran sehingga pembelajaran akan lebih terarah, terorganisir, dan tersistematisasi

\footnotetext{
* Mahasiswa SPS UPI
}

dalam upaya mencapai tujuan pembelajaran.

Dalam proses pembelajaran interaksi antara pendidik dengan peserta didik saling mempengaruhi hasil belajar. Oleh karena itu, pendidik harus memperhatikan berbagai faktor baik internal maupun eksternal sehingga situasi belajar menjadi situasi yang kondusif bagi terjadinya proses belajar. Agar pendidik dapat menyediakan situasi dan kondisi yang kondusif maka pendidik hendaknya menyusun langkah-langkah atau tahapan pembelajaran sehingga proses belajar akan lebih sistematis sehingga mudah untuk dikontrol.

Pelaksanaan pembelajaran yang baik dipengaruhi oleh perencanaan yang baik pula. Pembelajaran berintikan interaksi antara pendidik dengan peserta didik dalam proses belajarmembelajarkan. Proses belajar dan membelajarkan merupakan dua hal yang berbeda tetapi membentuk suatu-kesatuan, ibarat sebuah mata uang yang bersisi dua. Belajar merupakan kegiatan yang dilakukan oleh peserta didik atau warga belajar sedangkan membelajarkan adalah kegiatan yang dilakukan oleh pendidik yang sangat mempengaruhi kegiatan belajar peserta didik atau warga belajar.

Apabila pendidik membelajarkan dengan pendekatan yang bersifat menyajikan atau ekspositori maka para peserta didik atau warga belajar akan belajar dengan cara menerima, dan apabila guru membelajarkan dengan pendekatan lebih mengaktifkan peserta didik atau warga belajar maka para peserta didik atau warga belajar akan belajar dengan aktif pula.

Kegiatan pembelajaran terjadi melalui interaksi antara peserta didik di satu pihak dengan pendidik dipihak lainnya. Dalam kegiatan belajar kelompok 
interaksi itu terjadi pula di antara peserta didik. Interaksi antara peserta didik dengan pendidik atau antara peserta didik yang berada dalam situasi kegiatan pembelajaran. Kegiatan pembelajaran dilakukan oleh peserta didik dan kegiatan membelajarkan dilakukan oleh pendidik. Kegiatan pembelajaran dalam pendidikan nonformal tentu saja tidak sebagaimana umumnya dilakukan dalam pendidkan formal (Sudjana, 2005:95).

\section{PEMBAHASAN}

Menurut Leithwood dalam Seller dan Miller (1985:265) implementasi pembelajaran adalah proses penyesuaian konsep pembelajaran dengan kemampuan dan keadaan peserta didik. Dalam implementasi biasanya terjadi gap sehingga konsepsi-konsepsi pembelajaran memerlukan penyesuaian-penyesuaian. Pembelajaran atau pembelajaran pada dasarnya merupakan kegiatan belajar membelajarkan yang melibatkan pendidik dan peserta didik baik yang terjadi di kelas maupun di luar kelas ataupun di luar sekolah. Melalui proses belajar tersebut terjadi perubahan, perkembangan, kemajuan, baik dalam aspek fisik motorik, intelektual, sosial emosional maupun sikap dan nilai.

Semakin besar perubahan atau perkembangan itu dapat dicapai oleh peserta didik atau warga belajar maka makin baiklah proses belajar. Proses belajar membelajarkan di sini adalah dalam rangka pendidikan dan di dalam pendidikan semua aktifitas dan perubahan serta perkembangan mengarah kepada yang baik. Perkembangan ke arah yang tidak baik, itu bukanlah pendidikan. Kegiatan pendidikan itu selalu normatif. Jadi, perubahan atau perkembangan yang diarahkan dalam proses belajar-membelajarkan juga adalah perubahan dan perkembangan yang sifatnya normatif atau digunakan secara normative (Syaodih, 2007:468).

Gagne, Brigs dan Wager (1992:194), mengemukakan bahwa belajar itu perubahan disposisi atau kemampuan seseorang yang dicapai melalui upaya orang itu dan perubahan itu bukan diperoleh secara langsung dari proses pertumbuhan dirinya secara alamiah. Dengan pengertian ini, belajar merupakan upaya yang disengaja oleh seseorang yang bertujuan untuk mencapai tujuan belajar. Tujuan pembelajaran merupakan komponen utama yang terlebih dahulu harus dirumuskan. Tujuan pembelajaran merupakan titik awal yang sangat penting dalam proses pembelajaran. Jenjang tujuan pembelajaran (1) tujuan institusional, (2) tujuan kurikuler, dan (3) tujuan instruksional. Dilihat dari kawasan (domain) atau bidang yang dicakup tujuan pembelajaran terdiri dari: (1) tujuan kognitif, meliputi pemahaman, pengetahuan, penerapan, analisis, sintesis, dan evaluasi; (2) tujuan psikomotor meliputi persepsi, kesiapan, respon terbimbing, dan adaptasi; serta (3) tujuan afektif meliputi penerimaan, penghargaan, karakteristik, dan pengorganisasian. Tujuan belajar harus sesuai dengan kebutuhan belajar peserta didik.

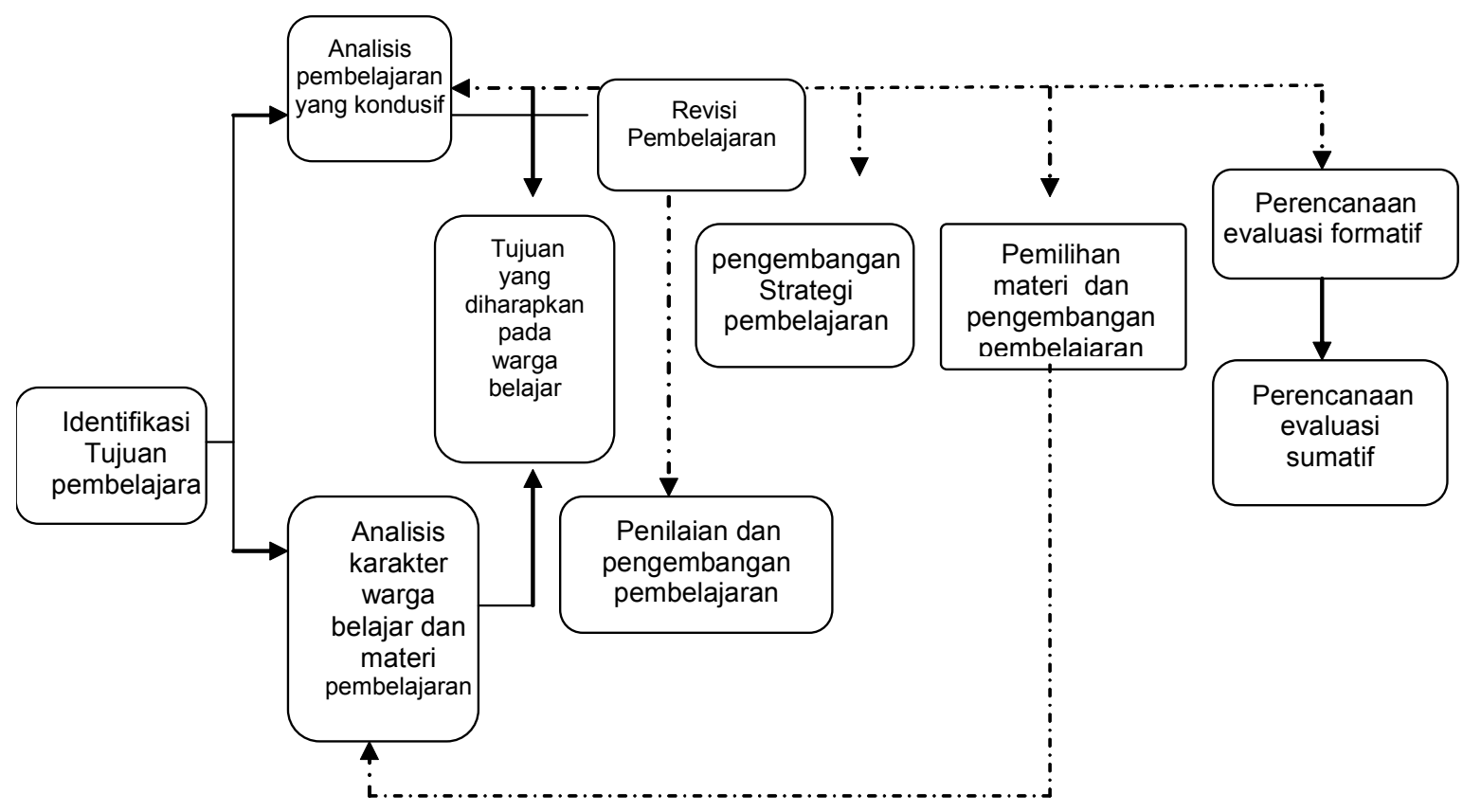

Gambar Identifikasi tujuan pembelajaran, diadopsi dari Dick, Carey and Carey (2001:16-17). 
Identifikasi tujuan pembelajaran sebagai kegiatan untuk menentukan ke mana arah pembelajaran sehingga perhatian pendidik dan peserta didik lebih terfokus dengan dukungan media pembelajaran. Analisis pembelajaran yang kondusif lebih tertuju pada kesiapan psikologis peserta didik dan dukungan lingkungan yang memungkinkan terjadinya proses pembelajaran. Analisis karakter peserta didik dan materi pembelajaran tentang bagaimana mengenal sifat-sifat peserta didik dan kesesuainnya dengan materi pembelajaran. Oleh karena itu, penentuan tujuan yang diharapkan adalah keterserapan materi sehingga terjadi perubahan perilaku bagi diri peserta didik.

Jika tujuan pembelajaran belum tercapai maka diadakan perbaikan sistem pengembangan materi pembelajaran, penentuan strategi pembelajaran yang tepat, penilaian formatif, dan sumatif. Penilaian formatif bertujuan untuk mengetahui daya serap peserta didik dalam berlangsungnya satu satuan materi pembelajaran sedangkan evaluasi sumatif bertujuan untuk mengetahui daya serap peserta didik diakhir proses penyajian satu materi pembelajaran. Untuk mencapai tujuan pembelajaran diperlukan pemahaman terhadap teori pembelajaran sebagaimana diuraikan sebagai berikut.

\section{Teori Belajar Behavioristik}

Teori behavioristik cenderung mengarahkan peserta didik atau warga belajar berpikir linier, tidak kreatif, dan tidak produktif. Pandangan teori behavioristik bahwa belajar merupakan proses pembentukan, pengetahuan adalah objektif, pasti, tetap, dan tidak berubah. Pengetahuan telah terstruktur dengan rapi sehingga belajar adalah perolehan pengetahuan sedangkan membelajarkan adalah memindahkan pengetahuan kepada peserta didik. Peserta didik diharapkan akan memiliki pengetahuan yang sama terhadap pengetahuan yang diajarkan.

Secara umum langkah-langkah pembelajaran yang berpijak pada teori behavioristik yang dikemukakan oleh Suciati, dkk dalam Budiningsih (2005:29), dapat digunakan dalam merancang pembelajaran, meliputi: (a) menentukan tujuan-tujuan pembelajaran; (b) menganalisis lingkungan kelas yang ada saat ini termsuk mengidentifikasi kebutuhan awal (entry behavior); (c) menentukan materi pelajaran; (d) me-mecahkan materi pelajaran meliputi pokok bahasan, subpokok bahasan, dan topik; (e) menyajikan materi pelajaran; (f) memberikan stimulus, berupa pertanyaan baik lisan maupun tulisan, latihan dan tugas-tugas; (g) mengamati dan mengkaji respon yang diberikan peserta didik; (h) memberikan stimulus baru; dan (i) memberikan penguatan (reinforcement) baik penguatan positif maupun penguatan negatif.

\section{Teori Belajar Kognitif}

Hakikat belajar menurut teori kognitif suatu aktivitas belajar yang berkaitan dengan penataan informasi, reorganisasi, dan proses internal. Kegiatan belajar yang berpijak pada teori belajar kognitif sudah banyak digunakan. Dalam merumuskan tujuan pembelajaran dan mengembangkan strategi pembelajaran tidak mekanistik seperti yang dilakukan dalam teori behavioristik. Kebebasan dan keterlibatan peserta didik secara aktif amat diperhitungkan agar belajar lebih bermakna bagi peserta didik. Menurut Budiningsih (2005:48-49) kegiatan pembelajarannya mengikuti prinsip-prinsip sebagai berikut.

1. Peserta didik atau warga belajar bukan sebagai orang dewasa yang muda dalam proses berpikirnya, mereka mengalami perkembangan kognitif melalui tahap-tahap tertentu.

2. Anak usia prasekolah dan awal sekolah dasar akan dapat belajar dengan baik, terutama jika menggunakan benda-benda konkret.

3. Keterlibatan peserta didik atau warga belajar dalam belajar amat dipentingkan karena hanya dengan mengaktifkan peserta didik atau warga belajar maka proses asimilasi dan akomodasi pengetahuan dan pengalaman dapat terjadi dengan baik.

4. Untuk menarik minat dan meningkatkan retensi belajar perlu meningkatkan pengalaman atau informasi baru dengan struktur kognitif yang telah dimiliki si belajar.

5. Pemahaman dan retensi akan meningkat jika materi pelajaran disusun dengan menggunakan pola atau logika tertentu, dari sederhana ke kompleks.

6. Belajar memahami akan lebih bermakna dari pada belajar menghafal.

7. Adanya perbedaan individual pada diri peserta didik atau warga belajar perlu diperhatikan karena faktor ini sangat mempengaruhi keberhasilan belajar peserta didik atau warga belajar.

Dalam kegiatan pembelajaran, keterlibatan peserta didik atau warga belajar secara aktif amat dipentingkan. Untuk menarik minat dan meningkatkan retensi belajar perlu mengkaitkan pengetahuan baru dengan struktur kognitif yang telah dimiliki siwa. Materi pelajaran disusun dengan menggunakan pola atau logika tertentu, dari sederhana ke kompleks. Perbedaan individual pada peserta didik atau warga belajar perlu diperhatikan karena faktor ini sangat mempengaruhi kegiatan belajar peserta didik atau warga belajar.

\section{Teori Belajar Humanistik}

Budiningsih (2005:68) menyatakan teori humanistik dengan pandangannya yang eklektik, yaitu dengan cara memanfaatkan atau merangkumkan berbagai teori be- 
lajar dengan tujuan untuk memanusiakan manusia bukan saja mungkin untuk dilakukan tetapi justru harus dilakukan. Selanjutnya pandangan Kolb dalam Budiningsih (2005) seorang ahli penganut aliran Humanistik membagi tahap-tahap belajar menjadi empat, yaitu (1) tahap pengalaman konkret, (2) tahap pengamatan aktif dan reflektif, (3) tahap konseptualisasi, dan (4) tahap eksperimentasi aktif serta tahap pengenalan konkret.

Pada tahap paling awal dalam peristiwa belajar adalah seseorang mampu atau dapat mengalami suatu peristiwa atau kejadian sebagaimana adanya, ia dapat melihat dan merasakannya, dapat menceritakan peristiwa tersebut sesuai dengan apa yang dialaminya. Tahap kedua dalam peristiwa belajar adalah bahwa seseorang makin lama akan semakin mampu melakukan observasi secara aktif terhadap peristiwa yang dialaminya. la mulai berupaya untuk mencarijawaban dan memikirkan kejadian tersebut. la melakukan refleksi terhadap peristiwa yang dialaminya dengan mengembangkan pertanyaan-pertanyaan bagaimana hal itu bisa terjadi dan mengapa hal itu mesti terjadi. Pemahamannya peristiwa yang dialaminya semakin berkembang yang terjadi pada seseorang pada tahap ke dua dalam proses belajar.

Tahap ketiga dalam peristiwa belajar adalah seseorang sudah mulai berupaya untuk membuat abstraksi, mengenal suatu teori, konsep atau hukum dan prosedur tentang sesuatu yang menjadi objek perhatiannya. Berpikir induktif banyak dilakukan untuk merumuskan suatu aturan umum atau generalisasi dari berbagai contoh peristiwa yang dialaminya. Walaupun kejadian-kejadian yang diamati tampak berbeda-beda namun memiliki komponen-komponen yang sama yang dapat dijadikan dasar aturan bersama. Tahap terakhir dari peristiwa belajar menurut Kolb dalam Budiningsih (2005) adalah melakukan eksperimentasi secara aktif. Pada tahap ini seseorang sudah mampu mengaplikasikan konsep-konsep, teori-teori atau aturanaturan, ke dalam situasi nyata. Berpikir deduktif banyak digunakan untuk mempraktekkan dan menguji teori-teori serta konsep-konsep di lapangan.

Dalam melaksanakan proses pembelajaran pendidikan nonformal perlu mengenal dan menerapkan berbagai tipe-tipe pembelajaran agar warga belajar tidak mencapai kulminasi kebosanan yang dapat mengakibatkan timbulnya malas belajar. Adapun tipe belajar tersebut adalah sebagai berikut.

\section{Tipe kegiatan belajar keterampilan}

Tipe kegiatan belajar keterampilan berfokus pada pengalaman belajar di dalam dan melalui gerak yang dilakukan peserta didik. Dalam buku psikologi belajar
Travers dalam Sudjana, (2005:120) dikemukakan bahwa gerak dapat disebut dengan berbagai istilah seperti motor learning, motor skills, psychomotor skils, skills, dan skills performance. Adapun yang dimaksud gerak ialah kegiatan badani yang disebabkan oleh adanya gerak, stimulus, dan respon yang tergabung pada situasi belajar. Ketiga unsur itu menumbuhkan pola gerak yang terkordinasi pada diri peserta didik.

Hubungan antara keterampilan intelek dan keterampilan gerak adalah keterampilan intelek berhubungan dengan kegiatan untuk memecahkan masalah, menyelenggarakan penelitian, dan menyelesaikan soal-soal. Adapun keterampilan gerak berhubungan dengan gerak badan untuk menghasilkan suatu benda. Dengan kata lain, keterampilan intelek lebih menekankan pada peningkatan kemampuan berpikir rasional sedangkan keterampilan gerak lebih mengutamakan gerakan badan.

2. Tipe kegiatan belajar pengetahuan

Kegiatan belajar masyarakat termasuk pada ranah kognitif (cognitive domain) yang dikemukakan Bloom dalam Sudjana (2005:129-131). Ranah ini mencakup pemahaman terhadap suatu pengetahuan, perkembangan kemampuan, dan keterampilan berpikir. Adapun yang termasuk kegiatan belajar pengetahuan adalah sebagai berikut.

a. Kegiatan belajar informasi, yaitu kegiatan belajar yang meliputi kegiatan peserta didik yang diprogramkan untuk memahami simbol dengan cara memformulasikan informasi yang bermakna bagi peserta didik dalam kehidupannya.

b. Kegiatan belajar konsep, yaitu sesuatu peristiwa yang terjadi disuatu tempat di mana seorang peserta didik mempelajari sesuatu yang berhubungan dengan kebutuhan belajarnya.

3. Tipe kegiatan belajar sikap

Patokan-patokan yang dapat digunakan pendidik dalam membantu peserta didik melakukan kegiatan belajar sikap adalah (1) susunlah tujuan kegiatan belajar besama-sama para peserta didik. Tujuan pembelajaran dapat menggambarkan tingkah laku yang menunjukkan adanya perubahan sikap yang dimiliki sekarang ke arah sikap yang diinginkan, (2) susun dan sajikan bahan belajar sebagai stimulus, (3) pendidik menumbuhkan suasana belajar partisipatif, (4) pendidik berusaha untuk menjadi contoh bagi peserta didik dalam melakukan tindakan yang sesuai dengan sikap baru yang telah ditentukan dalam tujuan belajar, (5) kegiatan belajar yang lebih mendukung tumbuhnya sikap baru perlu dilakukan melalui kegiatan belajar kelompok, (6) peserta didik yang telah menerima sikap baru diberi kesempatan untuk menyatakan pendapatnya secara 
terbuka kepada kelompoknya, dan (7) latihan untuk melakukan dan mengembangkan kegiatan peserta didik dalam sikap baru yang dimilikinya perlu diberikan (Sudjana, 2005:137).

\section{Tipe Kegiatan Belajar Pemecahan Masalah}

Masalah yang yang digunakan dalam pembelajaran memiliki arti tersendiri. Masalah yang dimaksud di sini ialah jarak antara sesuatu keadaan saat ini dengan keadaan yang diinginkan di masa yang akan datang (Sudjana, 2005:140). Sesuatu itu dapat berwujud pendidikan, kesehatan, pendapatan, dan pekerjaan.

Pemecahan masalah dalam arti luas adalah upaya yang dilakukan peserta didik untuk mencari dan menetapkan alternatif kegiatan dalam menjembatani suatu keadaan pada saat ini dengan keadaan yang diinginkan. Pentingnya masalah dan upaya pemecahannya dalam kegiatan belajar, didasari beberapa alasan adalah sebagai berikut.

a. Masalah dan upaya pemecahannya merupakan bagian dari kehidupan manusia secara alamiah.

b. Tingkat keberhasilan seseorang dalam kehidupannya sangat erat kaitannya dengan keberhasilan dalam pemecahan masalah yang dihadapi.

c. Upaya pemecahan masalah itu berangkai.

d. Bahwa dalam suatu masalah akan terdapat bagian-bagian masalah lain di dalamnya.

Tahap belajar yang lebih tinggi menurut Gagne dalam Ibrahim dan Syaodih (2003:37) adalah belajar pemecahan masalah. Dalam tipe pemecahan masalah peserta didik dihadapkan pada masalah-masalah yang harus dipecahkannya. Pemecahan masalah dapat dilakukan secara kelompok atau secara individual. Kegiatan belajar pemecahan masalah biasanya meliputi lima langkah, yaitu: (1) mengidentifikasi masalah; (2) merumuskan dan membatasi masalah, serta menyusun pertanyaan-pertanyaan; (4) mengumpulkan data; dan (5) merumuskan jawaban atas pertanyaanpertanyaan serta kesimpulan.

Untuk mensukseskan interaksi pembelajaran tidak cukup jika hanya mengetahui dan menerapkan tipe-tipe akan tetapi perlu didukung oleh pendekatan pembelajaran andragogi atau pendekatan pembelajaran yang ditujukan pada orang dewasa dalam konteks sistem pendidikan nonformal. Knowles dalam Abdulhak (2000:21) istilah "andragogy berasal dari "andr" dan "agogos". Dalam bahasa Yunani "andr" berarti orang dewasa dan "agogos" berarti memimpin atau membimbing. Andragogi dalam suatu model proses pembelajaran peserta didik.

Pendidikan Orang Dewasa (POD) dimaksudkan dengan usaha penyelenggaraan pendidikan bagi orang dewasa. Istilah POD mengandung adanya dua ungkapan, yaitu Pendidikan dan Orang Dewasa. Pendidikan orang dewasa merujuk pada penyelenggaraan pendidikan yang ditujukan bukan untuk anak-anak akan tetapi untuk orang dewasa. Hal ini didasarkan atas adanya dugaan bahwa terdapat perbedaan karakteristik antara pendidikan orang dewasa dengan pendidikan pada umumnya. Kedua istilah (pendidikan, dan orang dewasa) di atas perlu diungkapkan secara jelas supaya tidak banyak menimbulkan keraguan dalam memahaminya (Abdulhak, 2000:35).

Pendidikan orang dewasa mempunyai beberapa definisi, tergantung pada penekanan yang dibuat oleh penyusun definisi itu. Sebagai contoh, UNESCO dalam Lunandi (1982) mendefinisikan pendidikan orang dewasa adalah keseluruhan proses pendidikan yang diorganisasikan, apa pun isi, tingkatan, metodenya, baik formal atau tidak, yang melanjutkan maupun menggantikan pendidikan semula di sekolah, akademi dan universitas, serta latihan kerja yang membuat orang yang dianggap dewasa oleh masyarakat mengembangkan kemampuannya, memperkaya pengetahuannya, meningkatkan kualifikasi teknis atau profesionalnya, serta mengakibatkan perubahan pada sikap dan perilakunya dalam perspektif rangkap perkembangan pribadi secara utuh dan partisipasi dalam pengembangan sosial, ekonomi, dan budaya.

Pendidikan orang dewasa (andragogy) berbeda dengan pendidikan anak-anak (paedagogy). Pendidikan anak-anak berlangsung dalam bentuk identifikasi dan peniruan sedangkan pendidikan orang dewasa berlangsung dalam bentuk pengarahan diri sendiri untuk memecahkan masalah. Ada perbedaan antara anakanak dan orang dewasa jika ditinjau berdasarkan umur, ciri psikologis, dan biologis. Ditinjau dari segi umur, seseorang yang berumur antara 16 sampai dengan 18 tahun dapat dikatakan sebagai orang dewasa dan yang kurang dari 16 tahun dapat dikatakan masih anak-anak. Ditinjau dari ciri-ciri psikologis, seseorang yang dapat mengarahkan diri sendiri, tidak selalu tergantung pada orang lain, mau bertanggung jawab, mandiri, berani mengambil resiko dan mampu mengambil keputusan, orang tersebut dikatakan telah dewasa secara psikologis.

Istilah dewasa dapat ditinjau dari beberapa segi, yaitu dari segi biologis, hukum, sosial, dan psikologis. Orang dewasa didasarkan atas kelengkapan kondisi fisik, termasuk umur, dan juga kejiwaannya, serta dapat berperan sesuai dengan tuntutan tugas dari status yang dimilikinya. Berdasarkan umur menunjukkan bahwa yang disebut dewasa adalah setiap orang yang menginjak usia 21 tahun (meskipun belum menikah) 
atau semenjak seseorang menikah (meskipun belum berusia 21 tahun). Pendapat lain, diungkapkan Hurlock (1999:34) bahwa "adult (dewasa) atau "adulthood" (status dalam keadaan kedewasaan) ditujukan pada usia 21 untuk awal masa dewasa, dan sering pula dihitung sejak tujuh atau delapan tahun setelah seseorang mencapai kematangan seksual, atau sejak masa pubertas.

Pendekatan berdasarkan kepada umur ini dilakukan pula oleh ahli-ahli hukum sehingga melahirkan perbedaan perlakuan hukum terhadap setiap pelanggar. Bagi anak-anak dikelompokkan ke dalam Juvenile Deliquency atau kenakalan anak-anak sehingga penetapan hukumnya diatur tersendiri sedangkan kenakalan orang dewasa dikelompokkan ke dalam pelanggaran orang dewasa yang memiliki aturan secara khusus. Berdasarkan kejiwaan, pengertian dewasa itu ditunjukkan dengan adanya kematangan. Anderson (1989:312) menyusun tujuh ciri kematangan sebagai berikut.

a. Berorientasi pada tugas, bukan pada diri atau ego. Minat orang yang matang berorientasi pada tugas-tugas yang dikerjakannya dan tidak condong pada perasaan-perasaan diri sendiri atau untuk kepentingan pribadi.

b. Tujuan yang jelas dan kebiasaan-kebiasaan kerja yang efisien.

c. Mengendalikan perasaan pribadi dan dapat mempertimbangkan dalam bergaul dengan orang lain.

d. Memiliki pandangan yang objektif dalam setiap keputusannya.

e. Siap menerima kritik atau saran untuk peningkatan dirinya.

f. Bertanggung jawab atas segala usaha-usaha yang dilakukannya.

g. Dapat menyesuaikan secara realitas dalam situasi baru.

Ditinjau dari pengakuan tuntutan tugas, dewasa itu ditunjukan dengan adanya kewajiban melaksanakan tugas tertentu dalam kehidupan. Status kedewasaan menuntut peran tertentu yang harus dilakukan seseorang dalam kehidupannya sesuai dengan status yang dimilikinya, atau sudah menjadi penetapan dan pengakuan dari masyarakatnya (social recognition) bahwa dia dituntut untuk berbuat sesuai dengan status tersebut. Pada kehidupan masyarakat terdapat peranperan yang secara khusus yang hanya dapat dilakukan oleh orang dewasa.

Peran-peran tersebut di antaranya dalam membentuk rumah tangga baru, bekerja, dan kewajiban-kewajiban lain yang harus dilakukan sebagai anggota masyarakat. Dalam kaitannya dengan tugas perkembangan setiap perorangan, Havigurst dalam Ishak (2002:13-14) mengklasifikasikannya ke dalam tiga tahapan yang mencakup: (1) early adulthood (18-30 tahun), tugas kedewasaan pada tahap ini meliputi pemilihan calon pasangan untuk pembentukan keluarga, belajar untuk hidup bersama, memulai membentuk kehidupan keluarga, mendidik anak, dan memulai memantapkan kedudukan dalam pekerjaan; (2) middle age (35-60 tahun), tugas kedewasaan meliputi perolehan tanggung jawab sebagai warga negara dan anggota masyarakat, memantapkan standar kehidupan ekonomis, membantu anak untuk menjadi dewasa; dan (3) late maturity (65 tahun ke atas), tugas kedewasaannya meliputi penyesuaian diri dengan menurunnya fisik, dan pendapatan yang diperoleh. Pengertian istilah tersebut apabila kita gabungkan dalam istilah pendidikan orang dewasa dapat diartikan sebagai pendidikan yang ditujukan untuk peserta didik yang telah dewasa atau berumur 18 tahun ke atas atau telah menikah dan memiliki kematangan untuk memenuhi tuntutan tugas tertentu dalam kehidupannya.

\section{Implementasi Proses Pembelajaran Dalam Pendidikan Nonformal}

Dalam proses pembelajaran, keterlibatan peserta didik atau warga belajar secara aktif sangat penting untuk meningkatkan ingatan belajar perlu meningkatkan pengetahuan baru dengan struktur yang telah dimiliki peserta didik atau warga belajar. Perbedaan individual pada diri peserta didik atau warga belajar perlu diperhatikan karena faktor ini sangat mempengaruhi keberhasilan belajar peserta didik atau warga belajar. Dalam proses pembelajaran keterlibatan peserta didik sangat menentukan pencapaian tujuan pembelajaran. Keikutsertaan peserta didik diwujudkan dalam tiga tahapan kegiatan pembelajaran, yaitu perencanaan program (program planning), pelaksanaan (program implementation), dan penilaian program (evaluation) kegiatan pembelajaran.

Interaksi belajar-membelajarkan merupakan intraksi yang berencana. Secara umum yang menjadi rencana pembelajaran adalah kurikulum sedangkan secara khusus rencana pembelajaran Garis Besar Program Pembelajaran (GBPP) dan Satuan Pelajaran atau istilah sekarang Rancangan Program Pembelajaran (RPP). Kurikulum sebagai rencana pembelajaran yang bersifat umum, mengandung tujuantujuan yang ingin dicapai sedangkan rencana pembelajaran yang lebih khusus, yaitu GBPP Satuan Pelajaran yang merupakan penjabaran apa yang tercantum dalam kurikulum. Kegiatan belajar sebagai hasil dan belajar sebagai proses merupakan akibat 
berlangsungnya fungsi pembelajaran. Fungsi pembelajaran merupakan upaya mendorong, mengajak membimbing dan melatih yang dilakukan oleh pendidik supaya peserta didik melakukan kegiatan belajar untuk memenuhi kebutuhan belajar dan kebutuhan pendidikan dalam upaya memuaskan pemenuhan kebutuhan hidupnya.

Tujuan institusional suatu lembaga pendidikan perlu disusun sesuai dengan kebutuhan belajar yang dirasakan dan dinginkan oleh peserta didik sehingga tujuan tersebut sebagai milik peserta didik. Kegiatan belajar berorentasi pada tujuan yang dapat menimbulkan keterlibatan peserta didik agar peserta didik merasa puas apabila melakukan kegiatan belajar untuk mencapai tujuan belajar.

Implementasi teori belajar behavioristik dalam pembelajaran bahwa kegiatan belajar ditekankan sebagai aktivitas yang menuntut peserta didik atau warga belajar untuk mengungkapkan kembali pengetahuan yang sudah dipelajari. Penyajian materi pelajaran mengikuti urutan dari bagian-bagian keseluruhan. Pembelajaran dan evaluasi menekankan pada hasil dan evaluasi menuntut suatu jawaban benar. Jawaban yang benar menunjukkan bahwa peserta didik telah menyelesaikan tugas belajarnya.

Ada empat tahap perkembangan kognitif pada individu, yaitu (1) sensori motorik, (2) pra operasional (3) operasional konkrit, dan (4) operasi formal atau proporsional. Tahap-tahap perkembangan kognitif mempunyai implikasi praktis terhadap kegiatan pendidikan formal dan pendidikan nonformal adalah: (1) bahan belajar dan pengalaman belajar harus disajikan dalam bentuk yang konkrit dan berkaitan dengan kehidupan sehari-hari peserta didik, serta (2) mengutamakan pemberian kesempatan kepada peserta didik untuk belajar secara aktif dan partisipatif di dalam dan terhadap lingkungannya.

Tipe kegiatan pembelajaran keterampilan mengutamakan penggunaan teori perubahan perilaku. Tujuan tipe kegiatan belajar keterampilan adalah untuk membina dan mengembangkan penguasaan keterampilan bagi peserta didik pemula atau lanjutan sehingga keterampilan dapat dipelajari secara efisien dan efektif dengan didukung pengetahuan. Tipe kegiatan pembelajaran keterampilan memiliki kekurangan, yaitu sasarannya lebih jelas dan spesifik, prosedurnya efisien, pengawasan lebih kuat, pengaruh pembelajaran dapat diobservasi, tugas dapat disederhanakan, dan kecepatan belajar dapat disesuaikan dengan keinginan dan kemampuan peserta didik. Di samping kelebihan juga memiliki kelemahan, yaitu kurang menekankan pada proses kognitif, kebutuhan sosial, perasaan peserta didik, dan struktur yang mengikat.
Peranan pendidik adalah menyiapkan tujuan belajar, menyusun alat pengukuran perilaku peserta didik, sebelum dan sesudah pembelajaran, membuat analisis tugas, memilah-milah pengalaman belajar, mengukur perubahan perilaku, dan menggunakan teknologi yang cocok. Adapun peranan peserta didik adalah melibatkan diri secara langsung dalam proses pembelajaran, pada level psikomotorik yang didukung kognisi dalam kegiatan eksplorasi, praktik, dan umpan balik. Proses pembelajaran pada tipe pembelajaran pengetahuan menggunakan teori belajar kognitif dan teori belajar verbal. Tujuan yang ingin dicapai dalam proses pembelajaran pada tipe pembelajaran pengetahuan adalah menyampaikan atau menggambarkan informasi tentang tujuan yang harus dicapai.

Kelebihan tipe pembelajaran pengetahuan adalah informasi dapat disampaikan secara menyeluruh, proses pembelajarannya bisa bervariasi, dapat digunakan pada kelompok besar, dan hasil pembelajarannya dapat diukur. Adapun kekurangannya adalah kurang menekankan aspek pemecahan masalah, peserta didik pasif dalam pembelajaran, serta kebutuhan dan perasaan peserta didik kurang diperhatikan. Tujuan tipe pembelajaran sikap adalah untuk mengujii pendapat, sikap, dan keyakinan peserta didik serta membina dan mengembangkan kerja sama kelompok. Kelebihan tipe pembelajaran pengetahuan adalah semua peserta didik dapat menyumbangkan pikiran dan gagasannya, terbentuk kerja sama di antara para peserta didik, serta terjalin komunikasi interaktif dan metode pembelajarannya fleksibel. Kekurangan tipe ini adalah dapat menimbulkan kemaksaan peserta didik, menghindarkan tanggung jawab perorangan, sikap apatis, dan tidak fleksibel.

Tipe pembelajaran pemecahan masalah didasari oleh teori belajar menemukan dan mengungkapkan permasalahan (problem possing) dan belajar pemecahan masalah (problem solving). Tujuan pembelajarannya adalah untuk mengidentifikasi dan merumuskan masalah serta mengambil keputusan tentang alternatif pemecahan masalah. Peran pendidik dalam pembelajaran ini adalah menjelaskan teknik pemecahan masalah dan teknik pengambilan keputusan yang digunakan peserta didik, serta menerapkan studi kasus peserta didik berlatih dan mempratikkan pemecahan masalah. Peran peserta didik adalah berpartisipasi dalam memilih, mengunakan, dan memonitor model perubahan mental untuk mengatur kognitif dan mengaplikasikannya pada kasus pemecahan masalah. 


\section{KESIMPULAN}

Pembelajaran atau pengajaran pada dasarnya merupakan kegiatan pendidik untuk menciptakan situasi agar peserta didik belajar. Membelajarkan dan belajar merupakan kegiatan yang tidak dapat dipisahkan ibarat dua sisi mata uang. Belajar merupakan proses mental yang dinyatakan dalam berbagai perilaku, baik perilaku fisik, motorik maupun psikis. Meskipun sesuatu kegiatan belajar merupakan kegiatan fisik motorik tetapi di dalamnya terdapat kegiatan mental.

Dalam proses pembelajaran, interaksi antara peserta didik dan pendidik saling berpengaruh terhadap hasil belajar. Oleh karena itu, pendidik harus memperhatikan berbagai faktor baik internal maupun eksternal sehingga situasi belajar menjadi situasi yang kondusif bagi terjadinya proses belajar. Agar pendidik dapat menyedikan situasi dan kondisi yang kondusif maka pendidik hendaknya menyusun langkah-langkah pembelajaran sehingga proses belajar akan lebih sistematis sehingga mudah untuk diketahui dan dikontrol.

Proses pembelajaran pada dasarnya adalah interaksi instruksional antara pendidik dengan peserta didik. Pendidik dan peserta didik memiliki faktor-faktor tertentu yang berpengaruh terhadap hasil belajar. Oleh karena itu, faktor -faktor yang terdapat dalam diri peserta didik dan pendidik harus dikondisikan sehingga terjadi proses pembelajaran yang efektif. Begitu pula halnya dengan lingkungan pembelajaran, baik berupa materi, metode, media, dan sarana yang harus dikondisikan sedemikian rupa sehingga mendukung kegiatan pembelajaran. Penciptaan suasana proses pembelajaran merupakan tugas pendidik yang terwujud dalam langkah-langkah yang menyeluruh dan sistematis sejak awal sampai dengan proses pembelajaran yang merupakan satu kesatuan dan tidak terpisahkan. Keefektifan langkah-langkah pembelajaran yang ditempuh dapat diketahui hasilnya melalui evaluasi terhadap hasil belajar yang dicapai oleh peserta didik.

Kegiatan belajar sebagai hasil dan belajar sebagai proses merupakan akibat berlangsungnya fungsi pembelajaran. Fungsi pembelajaran merupakan upaya mendorong, mengajak, membimbing, dan melatih yang dilakukan oleh pendidik supaya peserta didik melakukan kegiatan belajar untuk memenuhi kebutuhan belajar dan kebutuhan pendidikan dalam upaya memuaskan pemenuhan kebutuhan hidupnya.

Pemecahan masalah menyangkut penggunaan keterampilan, pengetahuan dan sikap peserta didik untuk menghadapi masalah, pemecahan masalah menuntut peserta didik bersama pendidik untuk berpartisipasi aktif dalam mengidentifikasi masalah, merencanakan, melaksanakan, dan mengevaluasi program pemecahan masalah. Alat evaluasi yang dapat digunakan pada tipe belajar pemecahan masalah adalah instrumen, penilaian proses, penilaian hasil, dan dampak kegiatan.

\section{DAFTAR PUSTAKA}

Abdulhak, I. (2000). Metodologi pembelajaran orang dewasa. Bandung: Andira.

Anderson.(1989). The effective teacher (Studi guide and readings). New York: Mc. Graw-Hill Publishing.

Budiningsih. (2005). Belajar dan pembelajaran. Jakarta: Rineka Cipta.

Dick \& Carey (2001). The systematic design of instructional (Fifth edition). New York: Longman.

Gagne, Brigs, \& Wager. (1992). Principles of instructional design. USA: Jovanovich Publisher.

Hurlock, E. (1999). Perkembangan anak. (Alih bahasa Meitasarii Tjandrasa). Jakarta: Erlangga.
Ibrahim, R. \& Syaodih, N. (2003). Perencanaan pembelajaran. Jakarta: Rineka Cipta.

Lunandi, A.G. (1993). Pendidikan orang dewasa. Jakarta: PT. Gramedia Pustaka Utama.

Seller-Miller.(1985). Curriculum perspektives and practice. New York: Longman.

Sudjana. H.D. (2005). Strategi pembelajaran pendidikan luar sekolah. Bandung: Falah Production.

Syaodih. (2007). Bimbingan dan konseling. Bandung: Maestro.

(2003) Undang-Undang Nomor 20 Tentang Sistem Pendidikan Nasional. Jakarta: Depdiknas. 